\title{
ANÁLISE DE PHILOSOPHY AND MARTIAL ARTS DE GRAHAM PRIEST E DAMON YOUNG.
}

\author{
Carlos Herold Junior \\ Universidade Estadual de Maringá, Maringá, Paraná, Brasil. \\ Pedro Gil Parizotto \\ Universidade Estadual de Maringá, Maringá, Paraná, Brasil.
}

Se comparadas a outras práticas do corpo, as artes marciais se notabilizam por existirem entre discursos e representações de conotação filosófica. Professores e praticantes enxergam-se e se dão aos olhares como preocupados com a "tradição" ou a "filosofia" que embasa aquilo que praticam. Esse característico traço, todavia, até o momento não significou um ímpeto analítico que aproximasse as artes marciais da filosofia acadêmica resultante da pesquisa sistemática de autores e problemáticas. É essa a lacuna que Philosophy and martial arts ajuda a preencher. A coletânea de doze capítulos foi organizada por Graham Priest e Damon Young, filósofos da Universidade de Melbourne, sendo organizadas em três eixos: From philosophy to martial arts, From the martial arts to philosophy e Buddhism and other Asian philosophical traditions.

Na primeira parte, os quatro capítulos verificam "o que a reflexão filosófica pode nos ensinar a respeito das artes marciais, especialmente sobre a natureza e valor destas práticas" (p. 4).

Em The promise and the peril of the martial arts, Roberts-Thomson, sustentado em Aristóteles, sublinha que a relação entre artes marciais e o cultivo de virtudes é mais complexa do julga a "promessa" de que determinadas práticas (as artes marciais, neste caso) levariam seus praticantes à posse de virtudes. Para ele, são importantes as "[...] normas sociais e expectativas, que frequentemente acompanham este tipo de treinamento" (p. 25), o quê, a priori, pode ter lugar qualquer outra modalidade.

O capítulo 2 intitula-se Practicing Evil. Gillian Russell considera que não é apenas para sociopatas e assassinos em série que a capacidade de machucar os outros é importante: uma determinada pedagogia da dor infligida acontece também com artistas marciais. Essa competência possibilitaria pensar que "ser um excelente artista marcial e ser uma pessoa boa, são coisas simplesmente diferentes" (p. 45), a depender das consequências dessa pedagogia.

Em Martial arts and moral life, Sylvia Burrow focaliza a exposição de mulheres a situações de violência, ponderando que as artes marciais podem ser direcionadas para o incremento da autoconfiança necessária às mulheres para contornarem essas situações. Nesse sentido, mesmo sem mencioná-la, Burrow complementa a reflexão feita por Russell. Afinal, para as mulheres, as artes marciais são importantes por ensiná-las a romper as barreiras que as impedem de "machucar os outros" não apenas nas lutas contra o machismo cotidiano, mas em uma situação concreta de defesa pessoal, mormente, existente por conta da posição social ocupada pelas mulheres.

Fechando a primeira parte da coletânea, lemos The martial arts a philosophical practice. Nele, Lloyd apoia-se em Michel Foucault e Pierre Hadot para tomar a ideia de ser a filosofia um meio de vida. Ele pondera que, apesar da visibilidade das "asceses" produzidas no seio das artes marciais com sua carga religiosa e simbólica, haveria uma "relação problemáti- 
ca entre as artes marciais e a moralidade" (p. 83), entendendo que as artes marciais não são necessariamente "filosóficas", nos termos de Hadot: nem por serem orientais, nem por serem marciais ou nem por serem esportivas.

A segunda parte, From the martial arts to philosophy, apresenta a prática das artes marciais como elemento ético, estético e religioso, compreendendo o modo como elas "podem informar sobre temas filosóficos importantes por si mesmos" (p. 5).

Em Understanding quality and suffering through the martial arts, Bein expõe que a percepção da dor se dá através de aspectos qualitativos ao invés da quantidade de dor infligida. Por isso, a escolha entre o sofrimento do treinamento e a comodidade de uma vida sedentária levaria um artista marcial a preferir (e a justificar em termos "filosóficos") os hematomas e as escoriações.

A arte marcial como uma forma de autoapreciação é o assunto em Is proprioceptive art possible?, no qual Schrenk aborda a prática dos hyongs e dos katas. Neles, o praticante desenvolve a propriocepção e a criação de elementos artísticos na movimentação corporal. Todavia, a busca da perfeição não deveria se dirigir à gestualidade e sim à percepção interna dos movimentos realizados para que o praticante aproxime-se de si mesmo.

No capítulo A sublime peace são abordadas as capacidades mentais e estratégicas relacionadas à prática do Aikido. Barham assevera que o Aikido almeja a busca da paz sublime: "Esta apropriação surge com a aproximação da transcendência gradual dos valores normais do cotidiano [...]" (p. 124), sendo esta aproximação o efeito da apreciação do sublime que o autor enxerga como resultante das repetições de movimentos nos treinos.

No oitavo capítulo, On self-awareness and the self, os conceitos de consciência pessoal e esvaziamento de si mesmo do Zen Budismo e sua aplicação às artes marciais, são abordados. Neste sentido, a busca dos praticantes durante a luta deve ser um estado de alerta em relação a todas as coisas, abdicando da autoconsciência, mudando o foco do eu para o no-self, tendo como resultado uma resposta adequada a cada ação. Nesse processo, os artistas marciais estariam "autoconscientes sem se perceberem como si mesmos" (p. 136).

O último capítulo da segunda parte tem como título Mushin and flow. Nele, Krein e Ilundáin comparam o conceito oriental de Mushin (concentração cotidiana diante de situações de vida ou morte), e a concepção moderna de Flow (pico de performance, estado de consciência em que o esforço é percebido com muita facilidade). Os autores apontam similaridades entre os dois estados, apesar de eles serem percebidos diferentemente por praticantes de artes marciais no ocidente e oriente.

As tradições religiosas e filosóficas do oriente e suas relações com as artes marciais são abordadas na terceira parte, Buddhism and other Asian philosophical traditions. O entrelaçamento dos conceitos religiosos, filosóficos e marciais é avaliado em três capítulos.

No décimo capítulo, Ahimsa, Buddhism, and the martial arts, Schubert discute a aparente contradição entre o budismo e a violência das artes marciais. Para ele, embora algumas atitudes violentas possam causar dor, a dor gerada no final é menor do que a falta da ação (inação). No caso das artes marciais, essa inação se concretizaria na opção pela não prática em razão da violência.

The martial arts and buddhist philosophy apresenta a prática marcial como um meio para o desenvolvimento do budismo. Diversos elementos do budismo estão presentes no que o autor chama de "um bom treinamento", aquele capaz de desenvolver os princípios citados sem a necessidade de uma discussão sobre os mesmos. Evocando Aristóteles, Priest afirma que "é em nossas próprias práticas que desenvolvemos o tipo de pessoa que somos" (p. 199).

A coletânea se encerra com Bow to your enemies. Nele, Young examina a influência da religião através da análise do papel da cortesia nas artes marciais modernas do Japão. A cortesia no dojo manifestaria a união de três correntes religiosas (xintoísmo, confucionismo e zen-budismo) e o moderno pensamento oriental. A justificativa para a prática marcial imbrica- 
se à busca do caminho $(D o)$ que, trilhado no sofrimento dos treinos, desemboca na conquista de si mesmo sinalizada pela gentileza que se observa no praticante.

Um dos méritos da coletânea está no destaque a um terreno analítico pleno de possibilidades investigativas por todos aqueles que abordam as dimensões filosóficas socioculturais das lutas e artes marciais. Interessante constatar como diferentes tradições filosóficas são acionadas para pensar a prática das artes marciais, do mesmo modo que fica clara a condição de diferentes práticas corporais estimularem conceitos e reflexões variadas sobre pontos cruciais de problemáticas filosóficas, sobretudo, éticas e estéticas, para ficarmos no caso da coletânea. Características essas que começam a se mostrar em alguns trabalhos produzidos no campo da educação física no Brasil, mas ainda de modo bastante incipiente considerando o que lemos na coletânea e em muitas obras nela estudadas e referenciadas pelos autores no desenvolvimento de seus capítulos.

Duas características relativizam a positividade do conjunto dos textos acima apresentado. Em primeiro lugar, apesar de algumas breves passagens incidentais, principalmente no primeiro e quarto capítulos, a obra não oferece um panorama mais denso sobre a proximidade da filosofia em relação a essas práticas corporais. Permanece uma desconfortável (mas estimulante) inquietação sobre as razões (não apenas filosóficas, mas históricas, culturais e políticas) que tornam mais corriqueiro pensarmos em "dimensões filosóficas das artes marciais", sendo mais difícil enxergarmos as tais dimensões quando pensarmos nas ginásticas, nos esportes, nos lazeres etc. Relacionado a esse ponto, é possível verificar em algumas passagens de alguns capítulos que a postura analiticamente filosófica fica subordinada à corrente divulgação das artes marciais como "práticas dotadas de uma filosofia" e, por essa razão, melhor que as outras (principalmente, em termos pedagógicos). Detectar essas passagens pode ser um exercício necessário, pois, ao abordá-las, tomamos contato com a postura analítica mais recorrente em nosso contexto acadêmico quando se estuda (ou nas poucas vezes que se quer estudar) as artes marciais e a filosofia.

Por essas razões, a leitura de Philosophy and the martial arts poderá colaborar com o incremento desse tipo de reflexão no Brasil, na medida em que as artes marciais vêm ganhando não apenas visibilidade e adeptos, mas interessados em um entendimento mais profundo e sistematicamente construído sobre esse rico universo cultural.

\section{Referências}

PRIEST, G.; YOUNG, D. Philosophy and the martial arts. Abingdon and New York: Routledge, 2014.

Recebido em: $16 / 01 / 2019$

Revisado em: 22/02/2019

Aprovado em: 22/02/2019

Endereço para correspondência:

carlosherold@hotmail.com

Carlos Herold Junior

Universidade Estadual de Maringá, Departamento de Educação Física/UEM.

Avenida Colombo 5790

Jardim Universitário

85015430 - Maringá, PR - Brasil 